\title{
Personalized medicine: a windfall for science, but what about patients?
}

$\mathrm{P}$ ersonalized medicine is holding out the promise of administering medicines specifically tailored to a person's specific genome or metabolism - drugs that cure without adverse effects. ${ }^{1}$ No doubt, "stretch goals" and strong convictions help in the long and laborious struggle to unlock the mysteries of the human body.

Sequencing of the human genome was profoundly important science that led to fundamental shifts in our understanding of biology. We now appreciate that there are between 30000 and 40000 protein-coding genes in the human genome, not the more than 100000 previously thought. From an evolutionary perspective, this represents only about twice as many as in the worm or fly genome. ${ }^{2}$

In the world of cancer, genomics has yielded new molecular targets and therapeutic interventions, which have already been exploited, especially in patient selection, diagnosis and treatment. Genomics is also showing promise in cardiovascular disease, with substantial challenges remaining. ${ }^{3} \mathrm{We}$ are also better able to quantify the role of genes and genetic variation in disease and have learned that environmental influences are far more important than specific alterations in the genetic codes of common diseases. ${ }^{4}$

Continued work in genomics, proteomics and metabolomics will undoubtedly yield major discoveries about the inner workings of the human body. It may also yield more molecular targets, and promising diagnostic and therapeutic interventions are definitely within our grasp. ${ }^{1}$

Despite a few successes, patients would be foolhardy to expect anything more than a small number of additional tailored interventions. They should not expect the cures for all common diseases. First, because the interplay between genes, proteins, cell metabolism and the myriad environmental exposures are simply too complex to expect simple solutions, like a targeted molecule. And second, because getting any new therapy to market takes at least a decade.

However, from a patient's perspective, dubbing this work "personalized medicine" is not only unrealistic, but also has the potential to do more than just raise false hope and expectations. For the public at large, the term "personalized medicine" does not spark images of abstract science and technology. The image it creates is just the opposite: most people would conceive personalized medicine to be what's commonly called patient-centred or person-centred care - a more humane, empathetic approach to care focused on individuals and shaped by their needs and circumstances, rather than celllevel scientific manipulations. ${ }^{5}$

In fact, patient-centred care is the antithesis of the highlevel science some are trying to make sound more accessible and ordinary by using a down-to-earth label. And that confu- sion may cause collateral damage, distracting donors and governments from the important work of improving the quality of everyday care by making it more responsive to individuals and treating them with understanding and respect. In other words, it can lead to the continued disregard for the application of the soft, but nevertheless equally valid, science that supports such interventions that are applicable now. ${ }^{6}$

Studies that evaluate communication between patients and health providers, the optimal use of electronic information systems and even simple ideas such as encouraging patients to make lists of things to discuss with their physicians or coaching them on how to participate effectively in their medical consultation offer the real possibility of improving overall well-being as well as survival. But these studies get little attention or support. Might we use the label of "personalized medicine" to broaden the focus of scientifically validated interventions from genes to include behaviours as well?

Unfortunately, patient-centred care does not have the mystique of genes and beyond to draw support, but it offers the potential to radically change what patients go through — and improve outcomes relevant to patients as a result.

Ideally, we should avoid misinterpretations and exaggerated claims in our scientific discourse as well as in our choices of words and labels. Instead of wasting time re-engineering personalized medicine as a scientific label, let's work to increase funding for cutting-edge biological as well as behavioural, social and organizational scientific inquiry designed to better understand the more holistic view - recognizing each human life is a mix of biology, circumstances and needs. Perhaps there will even be a day when "personalized medicine" will invoke the same image in the worlds of both science and medicine.

\section{George Browman MDCM MSc, Paul C. Hébert MD MHSc, Jane Coutts BA BAA. With editorial advisory team: Matthew B. Stanbrook MD PhD, Ken Flegel MDCM MSc, Noni E. MacDonald MD MSc}

For references, see Appendix 1, available at www.cmaj.ca/lookup/suppl /doi:10.1503/cmaj.110607/-/DC1.

Competing interests: George Browman has been a paid consultant for Cancer Care Ontario. None declared by Jane Coutts. See www.cmaj.ca/site/misc /cmaj_staff.xhtml.

Affiliations: George Browman is Clinical Professor, School of Population and Public Health, University of British Columbia, Vancouver, BC, and Chair, Guidelines Advisory Group, Canadian Partnership Against Cancer, Toronto, Ont. Jane Coutts is an Ottawa-based writer and editor and president of Coutts Communicates. See www.cmaj.ca/site/misc/cmaj_staff.xhtml.

Correspondence to: $C M A J$ editor, pubs@cmaj.ca

Acknowledgement: George Browman is a member of CMAJ's Editorial Board.

CMAJ 2011. DOI:10.1503/cmaj.110607 